IZA DP No. 8419

Minimum Wage Systems and Earnings Inequalities:

Does Institutional Diversity Matter?

Andrea Garnero

Stephan Kampelmann

François Rycx

August 2014

Forschungsinstitut zur Zukunft der Arbeit Institute for the Study of Labor 


\title{
Minimum Wage Systems and Earnings Inequalities: Does Institutional Diversity Matter?
}

\author{
Andrea Garnero \\ ENS, Paris School of Economics, \\ SBS-EM (CEB, DULBEA) and IZA \\ Stephan Kampelmann \\ Université Libre de Bruxelles, SBS-EM (CEB, DULBEA) \\ François Rycx \\ Université Libre de Bruxelles, SBS-EM (CEB, DULBEA) \\ and IZA
}

Discussion Paper No. 8419

August 2014

IZA

P.O. Box 7240

53072 Bonn

Germany

Phone: +49-228-3894-0

Fax: +49-228-3894-180

E-mail: iza@iza.org

\begin{abstract}
Any opinions expressed here are those of the author(s) and not those of IZA. Research published in this series may include views on policy, but the institute itself takes no institutional policy positions. The IZA research network is committed to the IZA Guiding Principles of Research Integrity.

The Institute for the Study of Labor (IZA) in Bonn is a local and virtual international research center and a place of communication between science, politics and business. IZA is an independent nonprofit organization supported by Deutsche Post Foundation. The center is associated with the University of Bonn and offers a stimulating research environment through its international network, workshops and conferences, data service, project support, research visits and doctoral program. IZA engages in (i) original and internationally competitive research in all fields of labor economics, (ii) development of policy concepts, and (iii) dissemination of research results and concepts to the interested public.
\end{abstract}

IZA Discussion Papers often represent preliminary work and are circulated to encourage discussion. Citation of such a paper should account for its provisional character. A revised version may be available directly from the author. 


\section{ABSTRACT \\ Minimum Wage Systems and Earnings Inequalities: Does Institutional Diversity Matter? ${ }^{1}$}

This paper explores how the diversity of minimum wage systems affects earnings inequalities within European countries. It relies on the combination of (a) harmonized micro-data from household surveys, (b) data on national statutory minimum wages and coverage rates, and (c) hand-collected information on minimum rates from more than 1,100 sectoral-level agreements across Europe. The analysis covers 18 countries over the period 2007-2009. Empirical results confirm the intuition of many practitioners that the combination of sectoral minimum rates and high coverage of collective bargaining can, at least for earnings inequalities, be regarded as a functional equivalent to a binding statutory minimum wage at the national level. Regression results suggest indeed that both a national statutory minimum wage and, in countries with sectoral-level minima, a higher collective bargaining coverage are significantly associated with lower levels of (overall and inter-industry) wage inequalities and a smaller fraction of workers paid below prevailing minima. Several robustness checks confirm these findings.

JEL Classification: J31, J33, J51

Keywords: minimum wage systems, collective bargaining, wage inequality, Europe

Corresponding author:

François Rycx

Solvay Brussels School of Economics and Management (SBS-EM)

Université Libre de Bruxelles (ULB)

CP114/02, Avenue F.D. Roosevelt 50

1050 Brussels

Belgium

E-mail: frycx@ulb.ac.be

\footnotetext{
${ }^{1}$ The research in this paper has been funded by the European Trade Union Institute (ETUI). We are particularly grateful to Maria Jespen, Torsten Müller and Vera Glassner of the ETUI who have provided extremely constructive support and advice. We also would like to thank Martin Bauer, Lorenzo Birindelli, Reinhard Bispinck, Gerhard Bröthaler, Angela Golino, Ilkka Kaukoranta, Lena Larsen, Lene Paludan Hastrup, Pekka Sauramo, and Sepp Zuckerstätter, as well as the participants of the Belgian Day for Labour Economists (2012) in Leuven and the Eurofound expert meeting on minimum wages (2013) in Dublin. Elina Huttunen provided excellent research assistance. Any errors are obviously our own.
} 


\section{Introduction}

Few economic policies have sparked academic debates as long-lasting and as passionate as minimum wage policies. Several generations of economists have tabled evidence and counterevidence on the question whether a statutory wage floor is harmful for employment. The controversy is still ongoing but it seems that, in the end, any employment effects (be their positive or negative) are probably very small (Dolado et al., 1996; Dube et al., 2010; ILO, 2010) and mostly related to low-skilled and young workers.

However, since the mid-2000s a new minimum wage debate has stirred up much controversy in Europe (Schulten, 2012). The spark for this new debate has not been the employment effect, but the question of whether there is a case for a harmonized minimum wage policy at the European level. While prominent policymakers, leading scholars and parts of the trade union movement support the idea of European concertation on wage floors including some sort of harmonized minimum rate for all countries - there is also strong resistance from those advocating national autonomy and the preservation of institutional diversity.

Much of the antagonism brought about by the idea of a harmonized minimum wage policy in Europe stems from the fact that the current minimum wage arrangements differ widely among European countries. Objections are notably very strong in Austria, Italy, and the Nordic countries (see Eldring and Alsos (2012) for a detailed discussion) fearing that a European initiative could undermine the autonomy of the social partners and thereby jeopardize the entire process of bargaining. On the other hand, trade unions in countries like Germany and Spain favour a European approach to the issue to counterbalance the effect of decreasing coverage of collective agreements and the increase of low-wage jobs. 
The key factor that has worked against a European approach is the absence of a clear consensus at the European level on whether the benefits of harmonizing policies in this area outweigh the costs. However, the lack of empirical evidence as to the labour market consequences of different minimum wage systems certainly also explains the difficulty to reach an agreement.

The minimum wage chief aim is to set a floor at the bottom of the wage distribution in order to protect and sustain wages of the most vulnerable workers. Put differently, its primary goal is to curb wage inequalities. Yet, "there is very limited research explicitly focused on this [issue]" (Grimshaw, 2013: 3). The objective of this paper is to fill this gap (at least partially) by exploring the link between different institutional features of minimum wage systems and earnings inequalities within European countries. To do so, we combined (a) harmonized micro-data from household surveys, (b) data on national statutory minimum wages and coverage rates and (c) hand-collected information on minimum rates from more than 1,100 sectoral-level agreements across Europe. This effort notably allows us to assess the distributive outcomes of the minimum wage systems in Austria, Belgium, Cyprus, Denmark, Finland, Germany and Italy - all countries that are both absent from other empirical studies and among the main protagonists of the minimum wage debate at the European level. Overall, our data set covers 18 European countries over the period 2007-2009. ${ }^{2}$

The remainder of this paper is structured as follows. We start our analysis with a brief review of the literature regarding the relation between wage floors and distributive outcomes. Then, we present the key features of minimum wage systems in Europe as well as our analytical framework. Our data set, benchmark regression results and robustness tests are described in the ensuing section. The last section concludes.

\footnotetext{
${ }^{2}$ In addition to aforementioned countries, our data set includes information on Bulgaria, Estonia, France, Greece, Hungary, Ireland, Latvia, Poland, Portugal, Romania and the United Kingdom.
} 


\section{Review of the literature}

Minimum wages are typically designed to protect and sustain wages of the most vulnerable workers. They can have a role in sustaining income, reducing in-work poverty and low-wage work, and curbing wage inequalities. A rise in minimum wages can have opposing effects on income inequality: on the one hand, some people at the bottom of the distribution receive higher wages. On the other hand, it can lead to individuals leaving or partially retreating from the labour market. Freeman (1996) reviews the distributional consequences of minimum wages and concludes that the latter, if not too high, can improve the well-being of low wage earners and limit earnings inequality. Butcher et al. (2012) develop a model of wage-posting by employers where the labour supply to an individual employer is not perfectly elastic. Their model predicts that wage inequality will be affected by the minimum wage as it defines the level of the wage floor and generates spillover effects associated to job losses and 'wave effects' on earnings above the prevailing minimum. These spillovers, however, would dissipate as one moves up the wage distribution since far up the distribution very few workers are from segments where the minimum wage has a large impact on the earnings distribution.

Empirical results usually show that minimum wages reduce wage inequality (Brown, 1999; OECD, 1998; Rubery, 2003; Manning, 2003). Di Nardo et al. (1996) and Lee (1999), for instance, find that the fall in the real value of minimum wages explains a big share of the increase of the lower tail wage inequality in the US during the '80s. Autor et al. (2010) confirm the overall conclusion of previous estimates for the US. Keese (1998) and Lucifora et al. (2005) show that minimum wages reduce wage inequalities in Europe. In contrast, the European Commission (2008) analyses the effects of a range of wage-setting variables on wage dispersion in EU countries and finds no significant effect of minimum wages. At the more micro-level, Butcher et al. (2012) estimate a structural model taking both direct and 
spillovers effects into account and find that the introduction of the UK's National Minimum Wage explains more than 50 percent of the decline in wage inequality in the bottom half of the wage distribution between 1998 and 2010. Their results also confirm that spillovers are larger in low-wage segments.

Another issue at the core of the present paper is whether the diversity in minimum wage systems may lead to a diversity of outcomes. Among the few studies that address this question empirically is Boeri (2012). The latter compares different institutional settings in 66 countries by looking at the process of determination of statutory minimum wages and its effects on levels of minimum wages. He finds that a government legislated minimum wage, i.e. a setting characterised by the absence of consultation with the social partners, is significantly smaller than a wage floor set after formal consultations. According to the European Commission (2008), EU member states that have not introduced a national statutory minimum wage are countries with particularly strong bargaining institutions and actors. Moreover, in countries with statutory minimum wages, strong bargaining institutions would drive up the level of minimum wages.

In conclusion, previous research has devoted great attention to minimum wages and their effects on earnings inequalities. The current consensus suggests that minimum wages contribute to reduce wage inequalities and, if not too high, to improve the well-being of lowwage workers. It should be noted, however, that due to data limitations the vast majority of empirical studies has overlooked countries where minimum wages are set through collective agreements at the sectoral level. The potentially divergent outcomes between different minimum wage systems are thereby largely ignored in the literature. 


\section{Analytical framework}

This paper aims at analysing minimum wages not only in countries with statutory minimum wages at the national level, but also in countries in which wage floors are determined at the sectoral level through collective bargaining. Even though collectively agreed minimum wages are sometimes considered to be 'functional equivalents' of statutory wage floors (Schulten et al., 2006), we are interested in whether the two types of systems lead to different outcomes in terms of earnings inequalities. As far as we know, this research question has not been addressed elsewhere.

Given the importance and interactions between the collective bargaining coverage and the type of minimum wage that prevails in a given system (Grimshaw, 2013; Grimshaw et al., 2013), we propose to distinguish European countries with the help of a typology including:

- The collective bargaining coverage: the degree of coverage has been shown to influence the relative level of minimum wages, but also earnings inequalities.

- The mechanism of minimum wage setting: whether minimum wages are determined nationally as statutory wage floors or through collective bargaining at the sectoral level is likely to affect earnings inequalities. ${ }^{3}$

It should be noted that these two features of minimum wage systems are not entirely independent of each other and act in a complementary fashion (Grimshaw and Rubery, 2013). Indeed, a range of studies underline that the centralisation and coverage of collective bargaining tends to be higher in countries without statutory minima (Schulten et al, 2006; Vaughan-Whitehead, 2010; Eldring and Alsos, 2012; OECD, 2012). One reason for this is

\footnotetext{
${ }^{3}$ As in Boeri (2012), we also considered whether the national statutory minimum wage is set through a consultation or bargaining process. Regression results taking this additional information into account (not reported here due to space constraints but available on request) do not affect our conclusions.
} 
that statutory minimum wages are thought to protect workers against low wages in the absence of effective protection through collective bargaining. In other words, statutory minimum wages can be the consequence of low levels of collective bargaining if policymakers see them as an instrument to protect otherwise vulnerable workers. This explanation seems to account for minimum wage policies adopted by Central and Eastern European countries where collective bargaining institutions were so weak during the transition to capitalist labour markets that almost all countries installed statutory wage floors in order to protect workers against excessive wage dumping.

A central objective of minimum wage systems is to reduce wage inequality (Grimshaw and Rubery, 2013). Yet, it is not straightforward to define precisely what is meant by 'inequality'. Therefore, three complementary aspects are examined in this paper: a) overall wage inequality, measured by the Gini index ${ }^{4}$; b) wage inequality between industries, assessed through a Theil decomposition ${ }^{5}$; and c) the effective coverage as measured by the share of people paid below the minimum wage.

How are the different features of minimum wage systems related to these outcomes? In general, one might expect that more inclusive collective bargaining systems will be associated with lower levels of inequality: the compression of the overall wage structure is thus likely to be related to the share of employments covered by collective agreements. However, if trade union representatives only bargain for the interests of covered workers and

\footnotetext{
${ }^{4}$ The Gini index measures the extent to which the distribution of wages among workers deviates from a perfectly equal distribution.

${ }^{5}$ The Theil index is widely used to decompose total inequality into within- and between-group inequality. It is based on a formal similarity between distributions of probabilities and wage shares. We computed inter-sectoral Theil inequality as a share of total inequality in each country. This step is necessary given that only relative values of Theil inequality are comparable between countries. For an exposition of the Theil statistic and its axiomatic base, see Kamplemann (2009).
} 
are able to achieve higher wage rates for 'insiders' (covered workers) at the expense of lower rates for 'outsiders' (uncovered workers), the overall effect might be higher inequality. In particular, low levels of coverage might incite union leaders not to take outsider interests into account, which could lead to higher levels of wage inequality in the lower tail of the wage distribution. Even relatively stable and effective systems like the Austrian model, where obligatory membership in the Economic Chambers obliges all employers to adhere to collective bargaining agreements, leaves more and more groups of the labour force uncovered, in particular new kinds of self-employed individuals (Hermann, 2006). If many workers are not covered, then minimum wages can increase inequality and strengthen the divide between "insiders" and "outsiders".

As regards the mechanism of minimum wage setting, it appears reasonable to assume that wage inequalities are smaller in the presence of a national minimum wage than when wage floors are bargained at the sectoral level (cf. Grimshaw and Rubery, 2013). Indeed, the former mechanism is more likely to reduce wage dispersion in the lower tail of the distribution provided that non-compliance is limited. This idea is largely supported by the empirical literature on statutory minimum wages (Brown, 1999; Di Nardo et al., 1996; Lee, 1999; Autor et al., 2010). The consequences for lower-tail inequality of the two types of systems can easily be illustrated graphically. Comparing the examples of Finland and the United Kingdom in 2009, the lower tail of the Finnish wage distribution shown in Figure 1 displays some dispersion around the red lines representing sectoral minimum wages; this contrasts with the clean cut induced by the national minimum wage in the UK's wage distribution shown in Figure 2.

[Take in Figures 1 and 2] 
Since a national minimum wage is by definition the same for all workers whatever their sectoral affiliation, inter-industry wage inequality is also expected to be lower in the presence of a national statutory minimum. This idea is supported by Hermann (2005) who argues that the Austrian system of sectoral-level agreements leads to considerable wage inequality between sectors, an outcome that is qualified as a "grave disadvantage of the existing system".

Finally, one might assume that the share of workers paid below prevailing minima will be lower in countries with statutory minimum wages as in this case wage floors are set by law and information on their levels is probably more easily available to both employers and workers. In addition, it appears reasonable to hypothesize that higher collective bargaining coverage will lead to fewer workers paid below existing floors, especially in systems where the latter are bargained at the sectoral level (Grimshaw et al., 2013).

\section{[Take in Table 1]}

Table 1 summarises the diversity of European countries (included in our sample) with respect their collective bargaining coverage and minimum wage setting arrangements. The empty square in the upper left corner suggests that all countries provide at least some level of protection against low pay (through the existence of a national statutory minimum wage or at least a medium bargaining coverage). Eleven of the 18 countries in our sample are classified into one of the two squares associated with potentially equivalent levels of protection: Latvia, the United Kingdom, Ireland, Bulgaria, Estonia, Hungary, Portugal and Poland have a statutory minimum wage but low levels of collective bargaining coverage; Austria, Finland, Denmark and Italy have no statutory minima but high coverage. Belgium and France appear to be associated with dual protection, although in practice the French system probably 
provides no more protection that the two groups with potentially equivalent protection given that sectoral-level agreements often contain minimum rates that are actually below statutory wages (Gautié, 2010; Eldring and Alsos, 2012). The three remaining countries occupy intermediate positions: Romania and Greece arguably may provide somewhat stronger protection than the majority of countries with statutory minimum wages due to their relatively high levels of bargaining coverage. Conversely, the low coverage rates in Cyprus and Germany could mean that their minimum wage systems provide lower levels of protection compared to the other countries without statutory minimum wages. The weak position of the German minimum wage system in our table most likely reflects the ongoing debate on the introduction of a national minimum wage in this country and also illustrates why this debate may be livelier in Germany than in most other European countries.

\section{Data}

Our study is based on the combination of harmonized micro-data from household surveys; data on national statutory minimum wages and coverage rates; and hand-collected information on minimum rates from more than 1,100 sectoral-level agreements across Europe.

The representative micro-level data stem from the harmonized survey of European Statistics on Income and Living Conditions (EU-SILC). For the 18 countries in our sample, we used the available waves collected in 2008, 2009 and 2010 containing information on income variables for the years 2007-2009. The EU-SILC contains detailed information on job characteristics such as earnings, employment type and employer characteristics. On average, the micro-level information in our sample is based on 6,792 individual observations per country and year (see Appendix 1). 
The earnings variable used in the regression analysis is gross hourly wages. The latter have been calculated at the individual level by dividing gross monthly earnings - i.e. monthly wages before the deduction of taxes and including social contributions paid by the employee by the work hours the individual declared for the corresponding income period. We calculated this variable for all workers in the EU-SILC except for individuals who stated to be selfemployed; our analysis therefore includes individuals working part-time and all salaried employments. This is slightly different from other studies on minimum wages looking only at full-time workers or exclusively focusing on individuals paid hourly wages as opposed to monthly salaries (Schulten, 2006; Vaughan-Whitehead, 2010, Bureau of Labor Statistics, 2012).

Eleven countries in our sample have statutory minimum wages. For all countries, information on the level and evolution of these minima has been collected from the March 2012 edition of the WSI Mindestlohndatenbank ${ }^{6}$. The minimum rates have been collected and converted into euro amounts for all years with available EU-SILC microdata.

In light of the institutional set-up of the seven countries in our sample that do not have a national statutory minimum wage (Austria, Belgium ${ }^{7}$, Cyprus $^{8}$, Denmark, Finland, Germany, and Italy), access to minimum wage data for these countries is considerably more problematic. Indeed, this information had to be hand-collected from sectoral-level collective

\footnotetext{
${ }^{6}$ WSI data can be found at http://www.boeckler.de/wsi-tarifarchiv_7052.htm

${ }^{7}$ Belgium actually has a national minimum wage, but in addition to this statutory floor the collectively bargained minimum wages at the industry-level constitute the relevant minimum for most workers in this country. We have thus collected information on both the interprofessional and the sectoral-level minima and matched each individual to the minimum rate that corresponds to his or her profile.

${ }^{8}$ Cyprus is a special case in that the minimum wage is not defined at the sectoral but at the occupational level. For the period under analysis a single rate applied to around 10 occupational groups in Cyprus. We used data on these rates for 2007 and 2008 taken from EIRO country reports.
} 
bargaining agreements in each country. More precisely, we extracted from each agreement the wage assigned to the lowest category in collectively negotiated pay scales. While this definition of a sectoral minimum wage is straightforward, it should be noted that the elaborate categorisations that are found in many collective agreements render the identification of a given sectoral minimum wage relatively cumbersome. Indeed, in most agreements different pay scales co-exist: a separate pay scale is often defined for blue- and white-collar workers; specific scales are included for apprentices or young workers who enter the labour market; and even where a unique pay scale exists it is often differentiated by several variables such as occupational groups, work-post nomenclatures and seniority levels. In order to come closest to the conception of sectoral minimum wages as 'the pay rate defined for the lowest wage category', our database contains information on the pay rate of the lowest of any category that figures in all of the pay scales in a sectoral-level collective agreement, with the exception of pay scales for apprentices and young workers. In practice, in the vast majority of agreements this boils down to the pay rate that applies to workers with no seniority and who are classified in low-status occupations at the bottom of organisational hierarchies.

It should be noted that the number of sectoral-level collective agreements signed in most countries is significant. We therefore decided to collect minimum rates from a representative sample of sectoral-level collective agreements in each country and to use them to compute sectoral average minima at the NACE one-digit level. We notably extracted minimum rates from around 325 sectoral-level collective agreements from Austria (referring to wages in 2009); 150 from Belgium (wages in 2007); 105 from Denmark (wages in 2007, 2008 and 2009); 210 from Finland (wages in 2007, 2008 and 2009); 80 from Germany (wages in 2007); and 240 from Italy (wages in 2007, 2008 and 2009). In order to ensure the representativity of the sectoral-level minima in the final dataset, the calculation of average 
minimum rates at the NACE one-digit level takes into account the relative employment shares of the sampled sectors.

The information on collective bargaining coverage has been taken from Jelle Visser's (2011) ICTWSS data ${ }^{9}$, a standard reference in the literature on labour market institutions. We have used ICTWSS data corresponding to all 44 country-year observations in our sample, although it should be noted that the relative stability of coverage rates (or data on coverage rates) means that the temporal variability of this variable is low in most countries. The collective bargaining coverage is 29 percentage points higher in the sample of countries in which minimum wages are determined through collective bargaining at the sectoral level, reflecting a well-known relationship we already mentioned above (see Appendix 1). ${ }^{10}$

In all, our database contains 44 country-year observations (31 for countries with a statutory minimum wage and 13 for countries without) covering the period 2007-2009. Detailed descriptive statistics by country can be found in Appendix 1 .

\section{Results}

We estimate the following model:

$$
Y_{c, t}=\alpha+\beta_{1} N M W_{c}+\beta_{2} C B C_{c, t}+\beta_{3}\left(N M W^{*} C B C\right)_{c, t}+\beta_{4} \text { Kaitz index } \text { int }_{c}+X_{c, t} \delta+\tau_{t}+\varepsilon_{c, t}
$$

\footnotetext{
${ }^{9}$ ICTWSS data can be found at http://www.uva-aias.net/208

${ }^{10}$ Even if coverage and statutory floors may be historically related, over short time periods they can arguably be treated as being independent since it is costly and politically difficult to switch from one system to another. This short-run exogeneity is relevant for this study because the regressions presented in this section include both the coverage rate and the existence of a national minimum rate as explanatory variables and the potential bias of any long-run interdependence between the two is reduced since we have only a short time period (2007-2009).
} 
where the dependent variable denotes respectively the Gini index (overall wage inequality), the between-group Theil index (inter-industry wage inequality), and the share of people earning less than $75 \%$ of the corresponding minimum wage (at the national or NACE onedigit level) in country $c$ and year $t$. MWS is a dummy variable equal to 1 if the country has a statutory minimum wage and 0 otherwise. ${ }^{11} C B C$ measures the collective bargaining coverage. The interaction between $N M W$ and $C B C$ enables to test whether, as hypothesized, the collective bargaining coverage has a stronger negative impact on wage inequality in countries with sectoral wage floors. The Kaitz index is defined as the ratio of the minimum wage to the median wage of the working population. ${ }^{12}$ It reflects the 'bite' of the minimum wage: small values indicate that the floor is a long way from the centre of the earnings distribution and its impact therefore potentially low; conversely, a high Kaitz index reveals that the minimum wage is close to the centre of the distribution and that it potentially affects a larger number of employees. Ceteris paribus, we thus expect wage inequality indicators to depend negatively on the Kaitz index. $X$ is a vector of control variables, i.e. of time-varying country-specific characteristics. The latter include information (taken from the EU-SILC data) on shares of workers by occupation (3 categories), education (3 categories) and sex. $\tau$ denotes year dummies that control for business cycle effects. $\varepsilon$ is the usual error term.

\footnotetext{
${ }^{11}$ No country in our sample switched from a national- to a sectoral-level minimum wage (nor vice versa) over the period under investigation.

${ }^{12}$ In the case of countries in which wage floors are determined at the sectoral level, both the numerator and denominator of the Kaitz index include sectoral-level information.
} 
Overall wage inequality

Table 2 shows pooled OLS results of the estimation of equation (1) with the Gini index (overall wage inequality) as dependent variable. Models 1 to 5 report regression coefficients for our main variables of interest when moving progressively from a parsimonious to a more complete specification. Standard errors are robust to heteroscedasticity and autocorrelation.

[Take in Table 2]

The presence of a national minimum wage (NMW) and the collective bargaining coverage $(\mathrm{CBC})$ variable are systematically significant. The interaction effect between the CBC and the presence of a NMW, reported in Models 3-5, is also highly significant. In the most complete specifications (the last three models), the coefficient on NMW stands at -0.10 , which means that overall wage inequality is approximately 10 points of percentage smaller in countries with a statutory minimum wage. Moreover, estimates suggest that the Gini index decreases on average by 2.3 percentage points following a 10 percentage points increase in the $\mathrm{CBC}$. However, in countries with statutory minima the impact of the $\mathrm{CBC}$ on wage inequality is found to be much more limited. Indeed, the interaction effect between the CBC and the presence of a NMW almost entirely offsets the coefficient associated to the CBC. According to Model 5, a 10 percentage points increase in the $\mathrm{CBC}$ decreases wage inequality by only 0.4 percentage points in countries with statutory minima. As expected, we also find that wage inequality is lower in countries in which the minimum wage is closer to the centre of the overall wage distribution. Indeed, Model 4 indicates that a 10 percentage points increase in the Kaitz index decreases wage inequality on average by 1.3 points of percentage. Model 5 shows, in addition, that the relationship between these variables is quadratic. 
[Take in Table 3]

Table 3 reports pooled OLS estimates of equation (1) with the between-group Theil index (inter-industry wage inequality) as dependent variable. Regression results suggest that both the presence of a NMW and the $\mathrm{CBC}$ rate are negatively correlated with inter-industry wage inequality. In Models 3-5, inter-industry wage inequality is found to be between 1.2 and 1.6 percentage points smaller in countries with a statutory minimum wage. Moreover, estimates show that a 10 percentage points increase in the $\mathrm{CBC}$ decreases the inequality between sectors by around 2 percentage points. Yet, results of Model 5 suggest that the $\mathrm{CBC}$ has little impact on inter-industry wage inequality in countries with statutory minima. Indeed, the coefficient associated to the interaction variable between the presence of a NMW and the CBC is positive and almost equal (in absolute value) to that on the CBC. As regards the Kaitz index, it appears to have a negative and convex impact on inter-industry wage dispersion. An increase of the Kaitz index from 0.4 to 0.5 , for instance, is found to decrease the Theil index by 2.7 percentage points.

Share of workers paid below prevailing minima

[Take in Table 4]

Table 4 shows regression results using as dependent variable the share of workers earning less than 75 per cent of the corresponding minima. Findings are in line with those obtained for the overall and inter-industry wage inequality. Indeed, they highlight that the incidence of 
workers earning less than 75 per cent of the minimum wage: i) is on average between 12 and 15 percentage points smaller in the presence of a NMW; ii) diminishes on average by around 1.6 percentage points following a 10 percentage points increase in the $\mathrm{CBC}$ of a country with sectoral-level minima; iii) is almost not influenced by the CBC in countries with a NMW; and iv) depends negatively (but at a decreasing rate) on the level of the Kaitz index.

\section{Robustness tests}

Findings so far suggest that both a national statutory minimum wage and, in countries with sectoral-level minima, a higher $\mathrm{CBC}$ are significantly associated with lower levels of (overall and inter-industry) wage inequality and a smaller fraction of workers earning less than 75 per cent of the prevailing minima. As suggested by Schulten et al. (2006), it thus appears that the combination of sectoral minimum rates and high levels of $\mathrm{CBC}$ can, at least for earnings inequalities, be regarded as a functional equivalent to a binding statutory minimum wage at the national level.

We now focus on what are arguably the most relevant robustness tests and examine whether our conclusions are stable. First, we check the robustness of our estimations when regressions are run without countries with outlying values or systems, or when apprentices and very young workers are excluded from the sample. Next, we use an alternative threshold to measure the proportion of individuals paid below prevailing minima.

The Italian case is particular because its sectoral Kaitz indices are particularly high and in some cases even higher than 1 (i.e. a minimum wage higher than the median) pointing to a high incidence of non-compliance or exclusion (20 percent of Italian workers are paid below the rates fixed by sectoral-level agreements). It therefore appears that the high Kaitz indices we observe for Italy (see Appendix 1) should be interpreted with caution in light that their 
effective impact is relatively small compared to all other countries in our sample. In any case, results in columns 3, 7 and 11 of Appendix 2 show that our conclusions are not affected by the exclusion of Italy.

As for Belgium, the specificity of this country's minimum wage system is that it is the only one offering effective dual protection against low wages: it combines a national statutory minimum with high levels of collective bargaining coverage and binding wage floors defined in sectoral agreements. While the French system also combines a national minimum with sectoral bargaining, the collective agreements in France often fail to increase the minima above the national level (many collective agreements include wage floors below the SMIC that are therefore no relevant minima). The interpretation of the Belgian figures on sectoral minima is therefore slightly different compared to other countries in our sample, a difference that makes it worthwhile to test whether our conclusions change if Belgium is dropped from the sample. Findings in columns 4, 8 and 12 of Appendix 2 show that conclusions are not affected by the exclusion of Belgium.

Many countries and sectors differentiate applicable minima according to the employment status and age of individuals. This is notably the case for apprentices and employees younger than 18 and reflect the opinion shared by many policy makers and social partners that lower rates for these groups could curb negative employment effects. The practical difficulty of identifying reduced rates for apprentices and young workers in all country- and sectoral-level minima creates a potential bias in our database. In order to examine the scope of this issue, we have rerun all regressions after excluding apprentices and workers younger than 18 years from the EU-SILC. As shown in columns 2, 6 and 10, results are not affected if apprentices and young workers are eliminated from our sample.

Finally, we test the validity of our findings relative to the share of workers paid below the prevailing wage floors. To the extent that both the earnings variable and the hours measure 
are prone to measurement errors, it might be worthwhile to assess whether our results are sensitive to alternative definitions of this indicator. To address this issue, we have experimented with an alternative threshold, namely the share of workers earning less than 85 per cent of the prevailing minima. Again, the estimated coefficients, shown in Appendix 3, do not significantly differ from our baseline model.

\section{Conclusion}

Minimum wages have re-appeared on policy agendas across Europe. There are several factors that have contributed to this trend. On the one hand, in the richer EU countries the successive waves of enlargement have led to streams of low-wage immigration which are sometimes perceived as a threat to existing wage differentials. A stricter wage policy at the national or European level is seen by many as an attractive tool to curb the downward pressure on wages that is caused by low-wage immigration. On the other hand, the proportion of workers that are covered by collective agreements is dwindling in most Member States. Advocates of statutory minimum wages see them as an alternative tool that could substitute collective bargaining in protecting workers against low wages.

These developments, among others, have fuelled an ongoing debate at the European level as to whether it is desirable to implement a harmonized rate in all EU countries. We have argued that this debate lacks so far not only a framework that renders the opposing positions between different minimum wage institutions more intelligible, but the debate also lacks crucial empirical evidence as to the labour market outcomes associated with different minimum wage systems.

In this paper, we explored the link between different institutional features of minimum wage systems and earnings inequalities across European countries. To do so, we relied on the 
combination of harmonized micro-data from household surveys, data on national statutory minimum wages and coverage rates, and hand-collected information on minimum rates from more than 1,100 sectoral-level agreements across Europe. This effort notably allowed us to assess the distributive outcomes of the minimum wage systems in Austria, Belgium, Cyprus, Denmark, Finland, Germany and Italy - all countries that are both absent from other empirical studies and among the main protagonists of the minimum wage debate at the European level. Overall, our data set covers 18 European countries over the period 2007-2009.

Our results clearly underline the importance of thinking the European debate as a choice between different minimum wage systems rather than a choice of a certain rate to be harmonized across the EU. Crucially, we are able to show empirically what many practitioners long suspected: the combination of sectoral minimum rates and high coverage of collective bargaining can, at least for earnings inequalities, be regarded as a functional equivalent to a binding statutory minimum wage at the national level. Controlling for Kaitz indices, compositional and year effects, regression results suggest indeed that both a national statutory minimum wage and, in countries with sectoral-level minima, a higher collective bargaining coverage are significantly associated with lower levels of (overall and interindustry) wage inequalities and a smaller fraction of workers paid below prevailing minima.

Our results should be interpreted with caution notably because the lack of variability in institutional variables does not allow us to apply panel data techniques. Nevertheless, they contribute to the European minimum wage debate as they provide first empirical evidence regarding the distributive outcomes of different minimum wage systems beyond the traditional division between countries with and without a national statutory minimum wage. 


\section{References}

Autor D, Manning A and Smith C (2010) The contribution of the minimum wage to US wage inequality over three decades: a reassessment. NBER Working Paper 16533, Cambridge (Ma.).

Boeri T (2012) Setting the minimum wage. Labour Economics 19(3): 281-290.

Brown C (1999) Minimum wages, employment, and the distribution of income. In: Ashenfelter O and Card D (eds) Taxation, Welfare and the Crisis of Unemployment in Europe. Northampton: Edward Elgar, pp. 23-51.

Bureau of Labor Statistics (2012) Characteristics of Minimum Wage Workers: 2012. Washington DC: US Department of Labor.

Butcher T, Dickens R and Manning A (2012) Minimum wages and wage inequality: some theory and an application to the UK. CEP Discussion Paper 1177, London.

Di Nardo J, Fortin N and Lemieux T (1996) Labor market institutions and the distribution of wages, 1973-1992: a semiparametric approach. Econometrica 64(5): 1001-1044.

Eldring L and Alsos K (2012) European minimum wage: a Nordic outlook. Fafo Report 16, Oslo.

Dube A, Lester T and Reich M (2010) Minimum wage effects across state borders: estimates using contiguous counties. Review of Economics and Statistics 92(4): 945-964.

Dolado J, Kramarz F, Machin S, Manning A, Margolis D and Teulings C (1996) The economic impact of minimum wages in Europe. Economic Policy 23: 319-370.

European Commission (2008), Industrial Relations in Europe 2008. Brussels: European Commission.

Freeman R (1996) The minimum wage as a redistributive tool. Economic Journal 106(436): $639-649$. 
Gautié J (2010) France: towards the end of active minimum wage policy? In: VaughanWhitehead D. (ed.) The Minimum Wage Revisited in the Enlarged EU. Geneva: ILO, pp. $149-178$.

Grimshaw D (ed.) (2013) Minimum Wages, Pay Equity, and Comparative Industrial Relations. London: Routledge.

Grimshaw D and Rubery J (2013) The distributive functions of a minimum wage: first and second-order pay equity effects. In: Grimshaw D (ed.) Minimum Wages, Pay Equity, and Comparative Industrial Relations. London: Palgrave.

Grimshaw D, Bosch G and Rubery J (2013) Minimum wages and collective bargaining: what types of pay bargaining can foster positive pay equity outcomes? British Journal of Industrial Relations, forthcoming.

Hermann C (2005) Mindestlöhne in Österreich. FORBA Schriftenreihe 4, Wien.

Herman C (2006) Minimum wages in Austria. In: Schulten T, Bispinck R and Schäfer C (eds) Mindeslöhne in Europa. Hamburg: VSA-Verlag.

ILO (2010) Global Wage Report 2010/11: Wage Policies in Times of Crisis. Geneva: ILO.

Kampelmann S (2009) Inequality measures as conventions: new interpretations of a classic operationalization problem. Socio-Economic Review 7(4): 669-694.

Keese M (1998) Are statutory minimum wages an endangered species? In: Lucifora C and Salverda W (eds) Policies for Low Wage Employment and Social Exclusion. Rome: FrancoAngeli.

Lee D (1999) Wage inequality in the United States during the 1980s: rising dispersion or falling minimum wage? Quarterly Journal of Economics 114(3): 977-1023.

Lucifora C, McKnight A and Salverda W (2005) Low-wage employment in Europe: a review of the evidence. Socio-Economic Review 3(2): 259-292. 
Manning A (2003) The real thin theory: monopsony in modern labour markets. Labour Economics 10(2): 105-131.

OECD (1998) Employment Outlook. Paris: OECD.

OECD (2012) Employment Outlook. Paris: OECD.

Rubery J (2003) Pay equity, minimum wages and equality at work. ILO Working Paper 19, Geneva.

Schulten T, Bispinck R and Schäfer C (eds) (2006) Mindestlöhne in Europa. Hamburg: VSAVerlag.

Schulten T (2012) European minimum wage policy: a concept for wage-led growth and fair wages in Europe. International Journal of Labour Research 4(1): 85-103.

Vaughan-Whitehead D (ed.) (2010) The Minimum Wage Revisited in the Enlarged EU. Geneva: ILO.

Visser J (2011) ICTWSS: Database on Institutional Characteristics of Trade Unions, Wage Setting, State Intervention and Social Pacts in 34 countries between 1960 and 2007, Version 3. Amsterdam: AIAS. 
Figure1: Wage distribution and sectoral minimum wages in Finland

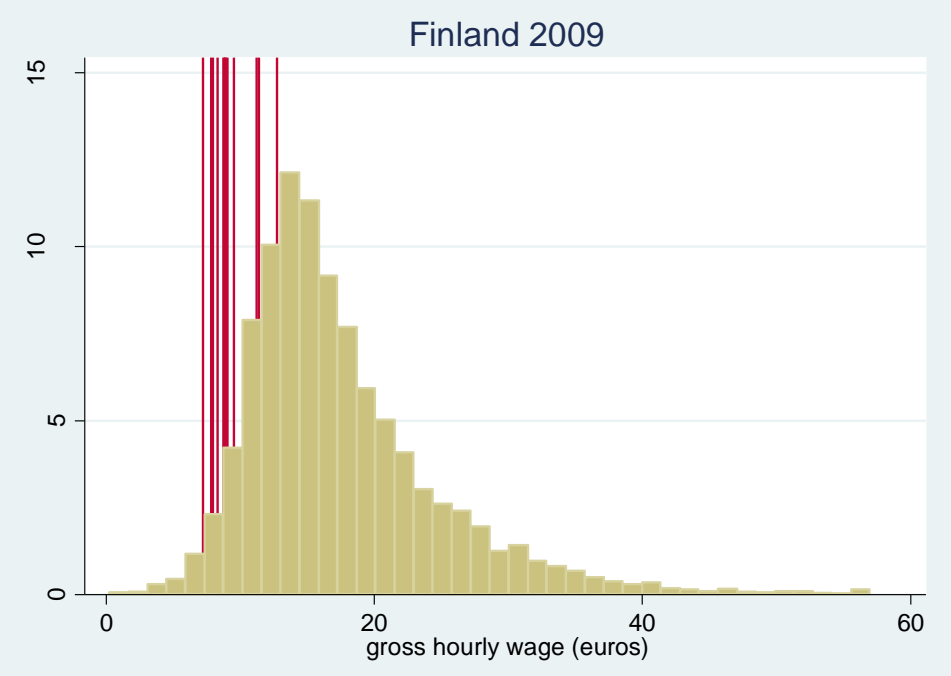

Source: FI-SILC; current 2009 euros; vertical red lines represent sectoral minima (in Helsinki for those sectors that have subminima outside Helsinki). 
Figure 2: Wage distribution and statutory minimum wage in the United Kingdom

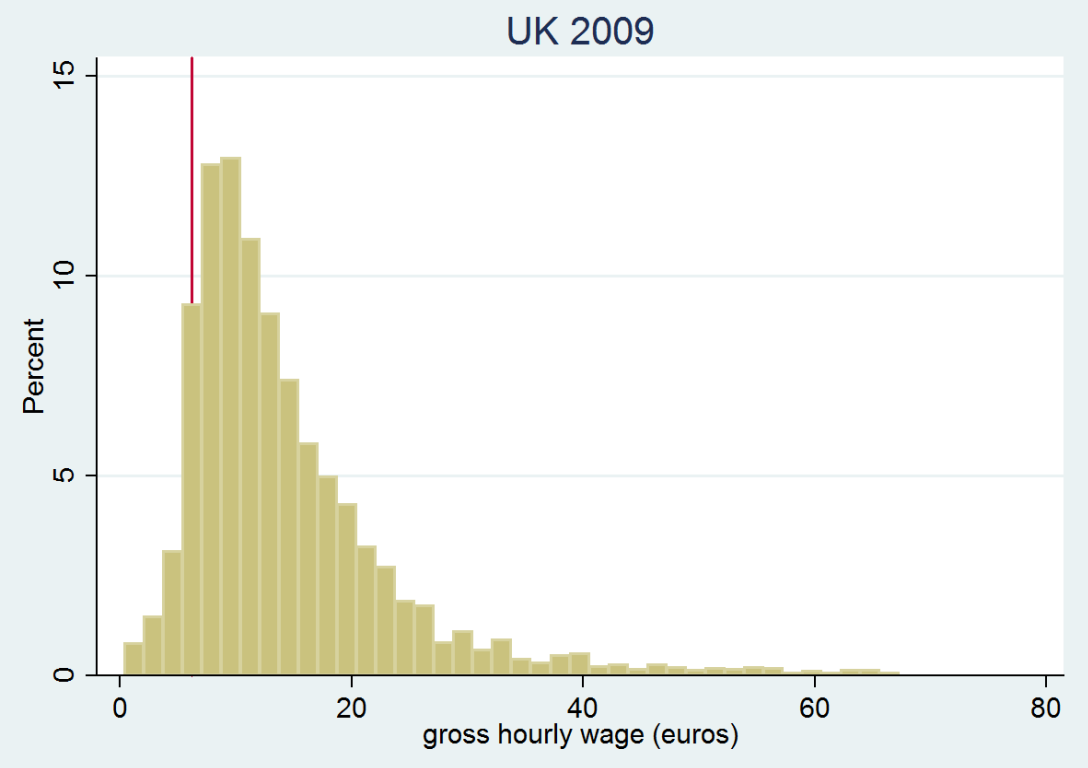

Source: UK-SILC; current 2009 euros; the vertical red line represents national statutory minimum wage. 
Table 1: Overview of countries according to their minimum wage (MW) systems

\begin{tabular}{|c|c|c|c|}
\hline & $\begin{array}{l}\text { Low bargaining } \\
\text { coverage }\end{array}$ & $\begin{array}{l}\text { Medium bargaining } \\
\text { coverage }\end{array}$ & $\begin{array}{l}\text { High bargaining } \\
\text { coverage }\end{array}$ \\
\hline Sectoral bargained MW & --- & Cyprus, Germany & $\begin{array}{l}\text { Austria, Finland, } \\
\text { Denmark, Italy }\end{array}$ \\
\hline National statutory MW & $\begin{array}{l}\text { Latvia, United } \\
\text { Kingdom, Ireland, } \\
\text { Bulgaria, Estonia, } \\
\text { Hungary, Portugal, } \\
\text { Poland }\end{array}$ & Romania, Greece & Belgium, France \\
\hline
\end{tabular}


Table 2: Overall wage inequality (Gini index)

\begin{tabular}{|c|c|c|c|c|c|}
\hline & Model 1 & Model 2 & Model 3 & Model 4 & Model 5 \\
\hline $\begin{array}{l}\text { National minimum wage } \\
\text { (NMW) }\end{array}$ & $\begin{array}{l}0.03 * * \\
(0.01)\end{array}$ & $\begin{array}{l}0.03 * * \\
(0.01)\end{array}$ & $\begin{array}{c}-0.09 * * \\
(0.04)\end{array}$ & $\begin{array}{c}-0.10 * * * \\
(0.03)\end{array}$ & $\begin{array}{c}-0.11 * * * \\
(0.03)\end{array}$ \\
\hline $\begin{array}{l}\text { Collective bargaining coverage } \\
\text { (CBC) }\end{array}$ & $\begin{array}{c}-0.10 * * * \\
(0.03)\end{array}$ & $\begin{array}{c}-0.12 * * * \\
(0.02)\end{array}$ & $\begin{array}{c}-0.24 * * * \\
(0.05)\end{array}$ & $\begin{array}{c}-0.24 * * * \\
(0.03)\end{array}$ & $\begin{array}{c}-0.23 * * * \\
(0.03)\end{array}$ \\
\hline $\mathrm{NMW} * \mathrm{CBC}$ & & & $\begin{array}{c}0.16 * * * \\
(0.05)\end{array}$ & $\begin{array}{c}0.17 * * * \\
(0.04)\end{array}$ & $\begin{array}{c}0.19 * * * \\
(0.04)\end{array}$ \\
\hline Kaitz index & & & & $\begin{array}{c}-0.13 * * * \\
(0.03)\end{array}$ & $\begin{array}{c}-0.47 * * \\
(0.19)\end{array}$ \\
\hline Kaitz index squared & & & & & $\begin{array}{l}0.26^{*} \\
(0.14)\end{array}$ \\
\hline Sex ratio & No & Yes & Yes & Yes & Yes \\
\hline Occupational controls & No & Yes & Yes & Yes & Yes \\
\hline Educational controls & No & Yes & Yes & Yes & Yes \\
\hline Year dummies & No & Yes & Yes & Yes & Yes \\
\hline Constant & $\begin{array}{c}0.35 * * * \\
(0.02)\end{array}$ & $\begin{array}{c}0.18 \\
(0.20) \\
\end{array}$ & $\begin{array}{c}0.13 \\
(0.17)\end{array}$ & $\begin{array}{c}0.48 * * \\
(0.19)\end{array}$ & $\begin{array}{c}0.52 * * \\
(0.19)\end{array}$ \\
\hline R-squared & 0.57 & 0.72 & 0.76 & 0.80 & 0.81 \\
\hline Observations & 44 & 44 & 44 & 44 & 44 \\
\hline F-test & 26.43 & 15.38 & 16.10 & 23.71 & 24.74 \\
\hline$p$-value & 0.00 & 0.00 & 0.00 & 0.00 & 0.00 \\
\hline
\end{tabular}

Significance levels: $* p<0.1, * * p<0.05, * * * p<0.01$. Robust standard errors. 


\begin{tabular}{lccccc}
\hline & Model 1 & Model 2 & Model 3 & Model 4 & Model 5 \\
\hline National minimum wage & & & & & \\
(NMW) & -0.01 & $-0.05^{* * *}$ & $-0.12^{* *}$ & $-0.12^{* *}$ & $-0.16^{* * *}$ \\
& $(0.03)$ & $(0.02)$ & $(0.06)$ & $(0.06)$ & $(0.05)$ \\
Collective bargaining coverage & & & & & \\
$(\mathrm{CBC})$ & -0.01 & $-0.13^{* * *}$ & $-0.20^{* * *}$ & $-0.20^{* * *}$ & $-0.20^{* * *}$ \\
& $(0.05)$ & $(0.03)$ & $(0.05)$ & $(0.05)$ & $(0.05)$ \\
NMW*CBC & & & 0.10 & 0.10 & $0.16^{* *}$ \\
& & & $(0.08)$ & $(0.08)$ & $(0.08)$ \\
Kaitz index & & & -0.03 & $-0.96^{* * *}$ \\
& & & & $(0.07)$ & $(0.33)$ \\
Kaitz index squared & & & & & $0.71^{* * *}$ \\
& & & & & $(0.25)$ \\
Sex ratio & No & Yes & Yes & Yes & Yes \\
Occupational controls & No & Yes & Yes & Yes & Yes \\
Educational controls & No & Yes & Yes & Yes & Yes \\
Year dummies & No & Yes & Yes & Yes & Yes \\
Constant & $0.12^{* * *}$ & 0.49 & 0.46 & 0.56 & $0.67 *$ \\
& $(0.05)$ & $(0.32)$ & $(0.32)$ & $(0.39)$ & $(0.37)$ \\
\hline R-squared & -0.05 & 0.55 & 0.55 & 0.54 & 0.59 \\
Observations & 44 & 44 & 44 & 44 & 44 \\
F-test & 0.03 & 27.94 & 35.98 & 34.74 & 27.07 \\
p-value & 0.97 & 0.00 & 0.00 & 0.00 & 0.00 \\
\hline Significance levels: $* p<0.1 * * *<0.05, * * *<0.01$. & Robust standard & errors. & & \\
& & & & &
\end{tabular}

Significance levels: $* p<0.1, * * p<0.05, * * * p<0.01$. Robust standard errors. 
Table 4: Share of workers earning less than 75 per cent of the corresponding minimum wage

\begin{tabular}{lccccc}
\hline & Model 1 & Model 2 & Model 3 & Model 4 & Model 5 \\
\hline $\begin{array}{l}\text { National minimum wage } \\
\text { (NMW) }\end{array}$ & $-0.03^{* *}$ & -0.02 & $-0.14^{* * *}$ & $-0.12^{* * *}$ & $-0.15^{* * *}$ \\
& $(0.01)$ & $(0.01)$ & $(0.03)$ & $(0.03)$ & $(0.03)$ \\
Collective bargaining coverage & & & & & \\
(CBC) & 0.01 & -0.03 & $-0.15^{* * *}$ & $-0.16^{* * *}$ & $-0.16^{* * *}$ \\
& $(0.02)$ & $(0.03)$ & $(0.04)$ & $(0.04)$ & $(0.04)$ \\
NMW*CBC & & & $0.16^{* * *}$ & $0.15^{* * *}$ & $0.19^{* * *}$ \\
& & & $(0.05)$ & $(0.04)$ & $(0.04)$ \\
Kaitz index & & & & $0.19^{* * *}$ & $-0.48^{* * *}$ \\
& & & & $(0.05)$ & $(0.13)$ \\
Kaitz index squared & & & & & $0.51^{* * *}$ \\
& & & & & $(0.12)$ \\
Sex ratio & No & Yes & Yes & Yes & Yes \\
Occupational controls & No & Yes & Yes & Yes & Yes \\
Educational controls & No & Yes & Yes & Yes & Yes \\
Year dummies & No & Yes & Yes & Yes & Yes \\
Constant & $0.05^{* * *}$ & $0.72 * * *$ & $0.67 * *$ & 0.16 & 0.24 \\
& $(0.02)$ & $(0.25)$ & $(0.25)$ & $(0.20)$ & $(0.18)$ \\
\hline R-squared & 0.25 & 0.39 & 0.46 & 0.69 & 0.80 \\
Observations & 44 & 44 & 44 & 44 & 44 \\
F-test & 3.93 & 3.29 & 8.69 & 7.26 & 11.81 \\
p-value & 0.03 & 0.01 & 0.00 & 0.00 & 0.00 \\
\hline Sign & & & & \\
& & & & &
\end{tabular}

Significance levels: $* p<0.1, * * p<0.05, * * * p<0.01$. Robust standard errors. 
Appendix 1: Descriptive statistics

\begin{tabular}{|c|c|c|c|c|c|c|c|c|c|c|c|c|c|}
\hline Countries & $\begin{array}{c}\text { Observations } \\
\text { per year }\end{array}$ & $\begin{array}{c}\text { SILC waves } \\
\text { used in empirical } \\
\text { analysis }\end{array}$ & $\begin{array}{c}\text { National } \\
\text { statutory } \\
\text { minimum } \\
\text { wage }\end{array}$ & $\begin{array}{c}\text { Collective } \\
\text { bargaining } \\
\text { coverage }\end{array}$ & $\begin{array}{l}\text { Average } \\
\text { Kaitz } \\
\text { index }\end{array}$ & $\begin{array}{c}\text { Average } \\
\text { minimum } \\
\text { wage }\end{array}$ & $\begin{array}{c}\text { Share of } \\
\text { women }\end{array}$ & 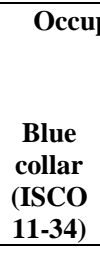 & $\begin{array}{l}\text { White } \\
\text { collar } \\
\text { (ISCO } \\
\text { 41-52) } \\
\end{array}$ & $\begin{array}{c}\text { Managers } \\
\text { (ISCO } \\
\text { 61-93) } \\
\end{array}$ & $\begin{array}{c}\text { ISCED } \\
\text { levels } \\
0,1,2 \\
\end{array}$ & $\begin{array}{c}\text { ISCED } \\
\text { levels } \\
\mathbf{3 , 4} \\
\end{array}$ & $\begin{array}{c}\text { ISCED } \\
\text { levels } \\
5,6 \\
\end{array}$ \\
\hline Austria & 5,409 & 2010 & No & 0.99 & 0.55 & 7.64 & 0.47 & 0.35 & 0.31 & 0.34 & 0.17 & 0.65 & 0.18 \\
\hline Belgium & 5,438 & 2008 & Yes & 0.96 & 0.59 & 9.15 & 0.47 & 0.41 & 0.30 & 0.29 & 0.19 & 0.39 & 0.42 \\
\hline Bulgaria & 5,399 & $2008-2010$ & Yes & 0.32 & 0.43 & 0.63 & 0.47 & 0.24 & 0.24 & 0.51 & 0.16 & 0.61 & 0.23 \\
\hline Cyprus & 3,429 & 2008-2009 & No & 0.52 & 0.51 & 4.65 & 0.49 & 0.38 & 0.30 & 0.32 & 0.19 & 0.42 & 0.39 \\
\hline Germany & 10,744 & 2008 & No & 0.63 & 0.54 & 7.64 & 0.49 & 0.51 & 0.24 & 0.24 & 0.08 & 0.52 & 0.40 \\
\hline Denmark & 4,373 & $2008-2010$ & No & 0.80 & 0.62 & 13.88 & 0.48 & 0.43 & 0.23 & 0.34 & 0.23 & 0.45 & 0.32 \\
\hline Estonia & 5,453 & $2008-2010$ & Yes & 0.21 & 0.44 & 1.61 & 0.53 & 0.40 & 0.18 & 0.42 & 0.10 & 0.54 & 0.36 \\
\hline Finland & 9,399 & $2008-2010$ & No & 0.90 & 0.59 & 8.85 & 0.51 & 0.42 & 0.26 & 0.32 & 0.15 & 0.48 & 0.37 \\
\hline France & 9,863 & 2009-2010 & Yes & 0.90 & 0.70 & 8.63 & 0.50 & 0.40 & 0.26 & 0.34 & 0.21 & 0.46 & 0.33 \\
\hline Greece & 4,365 & 2008-2010 & Yes & 0.65 & 0.45 & 3.87 & 0.45 & 0.30 & 0.35 & 0.36 & 0.22 & 0.44 & 0.34 \\
\hline Hungary & 7,690 & $2008-2010$ & Yes & 0.45 & 0.56 & 1.52 & 0.48 & 0.30 & 0.24 & 0.46 & 0.15 & 0.64 & 0.22 \\
\hline Ireland & 3,681 & 2008-2009 & Yes & 0.44 & 0.52 & 8.48 & 0.50 & 0.39 & 0.35 & 0.26 & 0.23 & 0.38 & 0.39 \\
\hline Italy & 13,450 & 2008-2010 & No & 0.80 & 0.91 & 10.41 & 0.44 & 0.32 & 0.27 & 0.41 & 0.37 & 0.47 & 0.16 \\
\hline Latvia & 5,644 & $2008-2010$ & Yes & 0.25 & 0.40 & 1.30 & 0.52 & 0.38 & 0.21 & 0.41 & 0.14 & 0.58 & 0.28 \\
\hline Poland & 10,730 & $2008-2010$ & Yes & 0.38 & 0.52 & 1.66 & 0.49 & 0.34 & 0.23 & 0.43 & 0.07 & 0.67 & 0.26 \\
\hline Portugal & 4,216 & $2008-2010$ & Yes & 0.58 & 0.52 & 2.57 & 0.48 & 0.23 & 0.29 & 0.49 & 0.65 & 0.19 & 0.16 \\
\hline Romania & 5,269 & 2008-2009 & Yes & 0.70 & 0.47 & 0.75 & 0.44 & 0.31 & 0.22 & 0.47 & 0.11 & 0.69 & 0.20 \\
\hline United Kingdom & 6,866 & 2008-2010 & Yes & 0.34 & 0.54 & 6.90 & 0.51 & 0.43 & 0.33 & 0.24 & 0.12 & 0.52 & 0.37 \\
\hline $\begin{array}{l}\text { Countries } \\
\text { without national } \\
\text { minimum wage } \\
\text { Countries } \\
\text { with national } \\
\text { minimum wage }\end{array}$ & 6,263 & & Yes & 0.50 & 0.50 & 3.39 & 0.49 & 0.34 & 0.26 & 0.40 & 0.20 & 0.52 & 0.30 \\
\hline Total & 6,792 & & - & 0.60 & 0.55 & 5.21 & 0.48 & 0.35 & 0.26 & 0.38 & 0.20 & 0.51 & 0.29 \\
\hline
\end{tabular}


Appendix 2: Robustness tests excluding apprentices and young workers, Italy and Belgium

\begin{tabular}{|c|c|c|c|c|c|c|c|c|c|c|c|c|}
\hline \multirow[t]{3}{*}{ Dependent variable: } & \multicolumn{4}{|c|}{ Overall wage inequality (Gini coefficient) } & \multicolumn{4}{|c|}{ Inter-industry wage inequality (Theil decomposition) } & \multicolumn{4}{|c|}{ Share of workers paid less than $75 \%$ of MW } \\
\hline & (1) & (2) & (3) & (4) & (5) & (6) & (7) & (8) & (9) & (10) & (11) & (12) \\
\hline & $\begin{array}{c}\text { Baseline } \\
\text { model }\end{array}$ & $\begin{array}{c}\text { Excluding } \\
\text { apprentices } \\
\text { \& workers } \\
<=18 \text { years }\end{array}$ & $\begin{array}{l}\text { Excluding } \\
\text { Italy }\end{array}$ & $\begin{array}{c}\text { Excluding } \\
\text { Belgium }\end{array}$ & $\begin{array}{c}\text { Baseline } \\
\text { model }\end{array}$ & $\begin{array}{l}\text { Excluding } \\
\text { apprentices } \\
\text { \& workers } \\
<=18 \text { years }\end{array}$ & $\begin{array}{l}\text { Excluding } \\
\text { Italy }\end{array}$ & $\begin{array}{l}\text { Excluding } \\
\text { Belgium }\end{array}$ & $\begin{array}{c}\text { Baseline } \\
\text { model }\end{array}$ & $\begin{array}{c}\text { Excluding } \\
\text { apprentices } \\
\text { \& workers } \\
<=18 \text { years }\end{array}$ & $\begin{array}{l}\text { Excluding } \\
\text { Italy }\end{array}$ & $\begin{array}{c}\text { Excluding } \\
\text { Belgium }\end{array}$ \\
\hline \multirow[t]{2}{*}{$\begin{array}{l}\text { National minimum wage } \\
\text { (NMW) }\end{array}$} & $-0.11 * * *$ & $-0.11^{* * *}$ & $-0.13^{* * *}$ & $-0.11^{* * *}$ & $-0.16^{* * *}$ & $-0.16^{* * *}$ & $-0.19 * * *$ & $-0.15^{* *}$ & $-0.15^{* * *}$ & $-0.14 * * *$ & $-0.15^{* * *}$ & $-0.15^{* * * *}$ \\
\hline & $(0.03)$ & $(0.03)$ & $(0.03)$ & $(0.03)$ & $(0.05)$ & $(0.05)$ & $(0.05)$ & $(0.05)$ & $(0.03)$ & $(0.03)$ & $(0.03)$ & $(0.03)$ \\
\hline \multirow[t]{2}{*}{$\begin{array}{l}\text { Collective bargaining coverage } \\
\text { (CBC) }\end{array}$} & $-0.23 * * *$ & $-0.24 * * *$ & $-0.23 * * *$ & $-0.23 * * *$ & $-0.20 * * *$ & $-0.20 * * *$ & $-0.19 * * *$ & $-0.18^{* * *}$ & $-0.16^{* * *}$ & $-0.15^{* * *}$ & $-0.16^{* * *}$ & $-0.16 * * *$ \\
\hline & $(0.03)$ & $(0.03)$ & $(0.03)$ & $(0.03)$ & $(0.05)$ & $(0.05)$ & $(0.06)$ & $(0.05)$ & $(0.04)$ & $(0.04)$ & $(0.04)$ & $(0.03)$ \\
\hline \multirow[t]{2}{*}{$\mathrm{NMW} * \mathrm{CBC}$} & $0.19^{* * *}$ & $0.19 * * *$ & $0.23 * * *$ & $0.19^{* * *}$ & $0.16^{* *}$ & $0.16^{* *}$ & $0.23^{* * *}$ & $0.16^{*}$ & $0.19^{* * *}$ & $0.19 * * *$ & $0.19^{* * *}$ & $0.19^{* * *}$ \\
\hline & $(0.04)$ & $(0.04)$ & $(0.05)$ & $(0.05)$ & $(0.08)$ & $(0.07)$ & $(0.08)$ & $(0.08)$ & $(0.04)$ & $(0.04)$ & $(0.04)$ & $(0.04)$ \\
\hline \multirow[t]{2}{*}{ Kaitz index } & $-0.47 * *$ & $-0.48 * *$ & 0.55 & $-0.47 * *$ & $-0.96 * * *$ & $-0.96 * * *$ & 0.73 & $-0.97 * * *$ & $-0.48^{* * * *}$ & -0.21 & $-0.48 * * *$ & $-0.49 * * *$ \\
\hline & $(0.19)$ & $(0.19)$ & $(0.36)$ & $(0.19)$ & $(0.33)$ & $(0.33)$ & $(0.67)$ & $(0.32)$ & $(0.13)$ & $(0.23)$ & $(0.13)$ & $(0.13)$ \\
\hline \multirow[t]{2}{*}{ Kaitz index squared } & $0.26^{*}$ & $0.28 *$ & $-0.79 * *$ & $0.27 *$ & $0.71 * * *$ & $0.71 * * *$ & -1.06 & $0.72 * * *$ & $0.51 * * *$ & 0.24 & $0.51 * * *$ & $0.53 * * *$ \\
\hline & $(0.14)$ & $(0.14)$ & $(0.36)$ & $(0.14)$ & $(0.25)$ & $(0.25)$ & $(0.66)$ & $(0.25)$ & $(0.12)$ & $(0.23)$ & $(0.11)$ & $(0.11)$ \\
\hline Sex ratio & Yes & Yes & Yes & Yes & Yes & Yes & Yes & Yes & Yes & Yes & Yes & Yes \\
\hline Occupational controls & Yes & Yes & Yes & Yes & Yes & Yes & Yes & Yes & Yes & Yes & Yes & Yes \\
\hline Educational controls & Yes & Yes & Yes & Yes & Yes & Yes & Yes & Yes & Yes & Yes & Yes & Yes \\
\hline Year dummies & Yes & Yes & Yes & Yes & Yes & Yes & Yes & Yes & Yes & Yes & Yes & Yes \\
\hline \multirow[t]{2}{*}{ Constant } & $0.52 * *$ & $0.46^{* *}$ & 0.21 & $0.52 * *$ & $0.67^{*}$ & $0.66^{*}$ & 0.18 & $0.68^{*}$ & 0.24 & 0.15 & 0.24 & 0.19 \\
\hline & $(0.19)$ & $(0.2)$ & $(0.19)$ & $(0.19)$ & $(0.37)$ & $(0.38)$ & $(0.32)$ & $(0.38)$ & $(0.18)$ & $(0.18)$ & $(0.19)$ & $(0.17)$ \\
\hline R-squared & 0.81 & 0.82 & 0.84 & 0.81 & 0.59 & 0.60 & 0.64 & 0.60 & 0.80 & 0.58 & 0.80 & 0.82 \\
\hline Observations & 44 & 44 & 41 & 43 & 44 & 44 & 41 & 43 & 44 & 44 & 41 & 43 \\
\hline F-test & 24.74 & 25.59 & 23.1 & 23.5 & 27.07 & 28.65 & 42.04 & 23.25 & 11.81 & 7.46 & 11.48 & 13.30 \\
\hline $\mathrm{p}$-value & 0.00 & 0.00 & 0.00 & 0.00 & 0.00 & 0.00 & 0.00 & 0.00 & 0.00 & 0.00 & 0.00 & 0.00 \\
\hline
\end{tabular}


Appendix 3: Share of workers earning less than 85 per cent of the corresponding minimum wage

\begin{tabular}{|c|c|c|c|c|c|}
\hline & Model 1 & Model 2 & Model 3 & Model 4 & Model 5 \\
\hline $\begin{array}{l}\text { National minimum wage } \\
\text { (NMW) }\end{array}$ & $\begin{array}{c}-0.04 * * \\
(0.02)\end{array}$ & $\begin{array}{l}-0.02 \\
(0.02)\end{array}$ & $\begin{array}{c}-0.16 * * * \\
(0.04)\end{array}$ & $\begin{array}{c}-0.13 * * * \\
(0.04)\end{array}$ & $\begin{array}{c}-0.17 * * * \\
(0.04)\end{array}$ \\
\hline $\begin{array}{l}\text { Collective bargaining coverage } \\
\text { (CBC) }\end{array}$ & $\begin{array}{c}0.02 \\
(0.02)\end{array}$ & $\begin{array}{l}-0.05 \\
(0.04)\end{array}$ & $\begin{array}{c}-0.18 * * * \\
(0.05)\end{array}$ & $\begin{array}{c}-0.19 * * * \\
(0.05)\end{array}$ & $\begin{array}{c}-0.19 * * * \\
(0.05)\end{array}$ \\
\hline $\mathrm{NMW} * \mathrm{CBC}$ & & & $\begin{array}{c}0.18 * * \\
(0.07)\end{array}$ & $\begin{array}{c}0.16^{* * * *} \\
(0.05)\end{array}$ & $\begin{array}{c}0.21 * * * \\
(0.05)\end{array}$ \\
\hline Kaitz index & & & & $\begin{array}{c}0.29 * * * \\
(0.06)\end{array}$ & $\begin{array}{c}-0.65^{* * *} * \\
(0.17)\end{array}$ \\
\hline Kaitz index squared & & & & & $\begin{array}{c}0.72 * * * \\
(0.15)\end{array}$ \\
\hline Sex ratio & No & Yes & Yes & Yes & Yes \\
\hline Occupational controls & No & Yes & Yes & Yes & Yes \\
\hline Educational controls & No & Yes & Yes & Yes & Yes \\
\hline Year dummies & No & Yes & Yes & Yes & Yes \\
\hline Constant & $\begin{array}{c}0.07 * * * \\
(0.02)\end{array}$ & $\begin{array}{c}1.01 * * * \\
(0.34)\end{array}$ & $\begin{array}{c}0.95 * * \\
(0.35) \\
\end{array}$ & $\begin{array}{c}0.17 \\
(0.27) \\
\end{array}$ & $\begin{array}{c}0.29 \\
(0.25) \\
\end{array}$ \\
\hline R-squared & 0.21 & 0.38 & 0.42 & 0.71 & 0.82 \\
\hline Observations & 44 & 44 & 44 & 44 & 44 \\
\hline F-test & 3.18 & 2.89 & 6.78 & 7.33 & 14.13 \\
\hline p-value & 0.05 & 0.01 & 0.00 & 0.00 & 0.00 \\
\hline
\end{tabular}

Significance levels: $* p<0.1, * * p<0.05, * * * p<0.01$. Robust standard errors. 